Berkinbayeva Ainur Nurkalievna, Cand. Tech. Sci. Institute of Metallurgy and Ore Benefication.

Almaty, the Republic of Kazakhstan

E-mail: ainur_kbk@mail.ru

https://orcid.org/0000-0002-2569-9087

\title{
STUDY OF PHYSICAL AND CHEMICAL, SORPTION PROPERTIES OF NATURAL SORBENTS (ZEOLITES)
}

\begin{abstract}
The article considers a comparative assessment of the chemical and phase composition of natural zeolites obtained at different horizons of ore bodies. It has been established that the main phases of zeolites are quartz, clinoptilolite, albite, diopside, hematite, lomontite, ernite. The sorption properties of the initial natural ion-exchange materials - a calcium type zeolite - in relation to uranium have been studied.
\end{abstract}

Keywords: natural sorbents, zeolite, uranium, sorption, sorption capacity.

For the extraction and removal of uranium from solutions and wastewater, various methods are used: ultrafiltration, nanofiltration, resin in the pulp, liquid membrane, biosorption, liquid extraction, ion exchange, solid-phase extraction, precipitation and electrodeposition. Among these methods, the ion exchange method using synthetic resins (organic sorbents) is the most popular, due to the selectivity and ability to regenerate resins [1 - 4]. A number of studies on the synthesis and modifications of sorbents developed by scientists [5 - 6] are known. However, the sorbents synthesized by them are mainly used for the sorption of non-ferrous, rare and noble metal ions in hydrometallurgy.

As for the sorption of uranium by inorganic sorbents, the authors of [7 - 9] give information on the sorption of uranium by natural zeolite. Natural zeolites and schungites are used in the field of environmental protection, for example, in the treatment of industrial wastewater from heavy metals, petroleum products, phenol, ammonium and radioactive elements. In addition to high ion-exchange and sorption properties, natural aluminosilicates and shungites are characterized by thermal, chemical, radiation resistance, mechanical strength and irreversibility of sorption. These physicochemical properties largely depend on the type of mineral and features of its structure: the size of the entrance windows of the framework, the volume of the cavities, the ratio of $\mathrm{Si} / \mathrm{Al}$, the composition and position of the cations. If it is necessary to clean large volumes of radioactively polluted water, the advantages of natural zeolites over synthetic sorbents are their low cost $(\$ 200$ 400 per ton), combined with fairly high sorption characteristics, as well as a wide prevalence. The listed advantages of natural sorbents make them very promising for the creation of new composite sorbents through chemical and physical modification.

Thus, the use of natural minerals, widely used in Kazakhstan, such as aluminosilicates, shungites, etc., is a promising direction in the field of creating domestic sorbents.

Therefore, it is important to study the composition, structure, physicochemical and sorption properties of natural zeolites to assess the possibility of their use for various purposes.

A comparative evaluation of the chemical and phase composition of the previously unexplored natural zeolites of Northern Kazakhstan of the Kusmurynskoye field, which are numbered No. 1, No. 2 and No. 3, was carried out. 
The elemental and phase composition of natural zeolites was determined using X-ray fluorescence and X-ray phase analyzes using X-ray fluorescence wave dispersion spectrometer of the Venus 200 company PANalyical and a Bruker diffractometer $(\mathrm{Cu}-\mathrm{K} \alpha$ radiation).

Table 1 presents the elemental composition of natural zeolites; according to $\mathrm{x}$-ray fluorescence analysis, in table 2 - phase.

From table 1 it follows that in addition to the aluminosilicate matrix, the composition of the initial zeolite includes "impurity metals", such as: $\mathrm{Fe}, \mathrm{Na}, \mathrm{Mg}, \mathrm{Ca}, \mathrm{Ti}, \mathrm{V}, \mathrm{Ba}, \mathrm{Cr}, \mathrm{Mn}, \mathrm{Cu}, \mathrm{Sr}, \mathrm{Rb}, \mathrm{Zn}$, $\mathrm{P}$ and etc.

Table 1 - The elemental composition of the original natural zeolites

\begin{tabular}{|c|c|c|c|}
\hline Chemical compounds & $\begin{array}{c}\text { Content in zeolite } \\
\text { No. } 1\end{array}$ & $\begin{array}{c}\text { Content in } \\
\text { zeolite No. 2 }\end{array}$ & $\begin{array}{c}\text { Content in zeolite } \\
\text { No. 3 }\end{array}$ \\
\hline $\mathrm{SiO}_{2}$ & 62.2 & 55.7 & 37.8 \\
\hline $\mathrm{Al}_{2} \mathrm{O}_{3}$ & 13.4 & 14.8 & 13.9 \\
\hline $\mathrm{Fe}_{2} \mathrm{O}_{3}$ & 5.9 & 11.3 & 33.3 \\
\hline $\mathrm{Na}_{2} \mathrm{O}$ & 1.6 & 8.6 & 5.4 \\
\hline $\mathrm{CaO}$ & 5.3 & 2.5 & 5.1 \\
\hline $\mathrm{K} 2 \mathrm{O}$ & 6.5 & 3.1 & 0.7 \\
\hline $\mathrm{MgO}$ & 2.2 & 2.3 & 1.3 \\
\hline $\mathrm{P}_{2} \mathrm{O}_{5}$ & 0.4 & 0.1 & 0.3 \\
\hline $\mathrm{MnO}_{\mathrm{TiO}}$ & 0.2 & 0.3 & 0.4 \\
\hline Other impurities & 0.5 & 0.2 & 1.5 \\
\hline $\mathrm{SiO}_{2} / \mathrm{Al}_{2} \mathrm{O}_{3}$ & 1.8 & 1.1 & 0.3 \\
\hline
\end{tabular}

The ratio of the main components of the $\mathrm{SiO}_{2} / \mathrm{Al}_{2} \mathrm{O}_{3}$ cations for zeolite No. 1 is 4.6 , for zeolite No. 2 it is 3.8, and for zeolite No. 3 it is 2.7 .

$\mathrm{SiO}_{2} / \mathrm{Al}_{2} \mathrm{O}_{3} \geq 4$ indicates the resistance of the studied zeolites to aggressive substances and high temperatures.

From the data obtained it follows that all three samples of zeolites are close in elemental composition, while the phase composition is somewhat different (Table 2).

Table 2 - Phase composition of the initial zeolites

\begin{tabular}{|l|l|c|c|c|}
\hline \multicolumn{1}{|c|}{ Name } & \multicolumn{1}{|c|}{ Formula } & Zeolite No. 1 & Zeolite No. 2 & Zeolite No. 3 \\
\hline Clinoptilolite & $(\mathrm{Na}, \mathrm{K}, \mathrm{Ca})_{6}(\mathrm{Si}, \mathrm{Al})_{36} \mathrm{O}_{72} .20 \mathrm{H}_{2} \mathrm{O}$ & 21.5 & - & - \\
\hline Quartz & $\mathrm{SiO}_{2}$ & 21.3 & 16.1 & 17.1 \\
\hline Albite & $\mathrm{Na}\left(\mathrm{AlSi}{ }_{3} \mathrm{O}_{8}\right)$ & 19.4 & 28.9 & 16.6 \\
\hline Diopside & $\mathrm{Ca}(\mathrm{Mg}, \mathrm{Al})(\mathrm{Si}, \mathrm{Al})_{2} \mathrm{O}_{6}$ & 13.9 & 11.1 & 12.9 \\
\hline Hematite & $\mathrm{Fe}_{2} \mathrm{O}_{3}$ & 9.3 & 7.2 & 7.6 \\
\hline Lomontite & $\mathrm{Ca}\left(\mathrm{H}_{2} \mathrm{O}\right) 2.8\left(\mathrm{Al}_{2} \mathrm{Si}_{4} \mathrm{O}_{12}\right)\left(\mathrm{H}_{2} \mathrm{O}\right) .5$ & 7.8 & 13.4 & - \\
\hline & $\left(\left(\mathrm{Fe}^{+2}, \mathrm{Fe}^{+3}, \mathrm{Al}\right) 3 \mathrm{Mg} 3(\mathrm{Ca}, \mathrm{Na}) 4(\mathrm{Si} 13.5 \mathrm{Al} 4\right.$ & & & \\
Erinite & $\left..5 \mathrm{O} 42)(\mathrm{OH})_{6}\right) \cdot 11.3 \mathrm{H}_{2} \mathrm{O}$ & 6.8 & 7.3 & 8.6 \\
\hline Calcite & $\mathrm{Ca}\left(\mathrm{CO}_{3}\right)$ & 10.4 & - & - \\
\hline Geylandit & $\mathrm{Na}_{2}\left(\mathrm{Al}_{8.9 S i 27.1 \mathrm{O} 72)\left(\mathrm{H}_{2} \mathrm{O}\right) 25.92}\right.$ & - & 16 & 18.9 \\
\hline Analcime & $\mathrm{NaAlSi}_{2} \mathrm{O}_{6}\left(\mathrm{H}_{2} \mathrm{O}\right)$ & - & - & 8 \\
\hline
\end{tabular}


The main minerals of sample No. 1 are calcium type clinoptilolite and quartz, and albite and diopside are present in a few smaller quantities. All three samples include minerals such as quartz, albite, diopsite, calcite, hematite. Sample No. 2 and No. 3, along with the indicated ones, includes geylandite, samples No. 1 and No. 2 contain lomantite, samples No. 1 contain clinoptilolite, and samples No. 3 contain analcite.

For subsequent studies, zeolite No. 1 was chosen, which has a higher silicate module and a more diverse phase composition.

The sorption properties of the original natural ion-exchange material - calcium type zeolite with respect to uranium were studied.

Sorption of uranium was carried out from the model solution with zeolite No. 1 in the static mode. A model uranium-containing solution was prepared by dissolving the standard in $5.0 \%$ sulfuric acid. The concentration of uranium in the model solution was $2.6 \mathrm{mg} / \mathrm{dm}^{3}$. The ratio $\mathrm{T}$ : $\mathrm{F}$ was 1:25. These sorption of uranium are given in Table 3. The calculations in the table are made on the basis of the results of the study of the content of uranium in the mother liquor after sorption.

Table 3 - Results of sorption of uranium from a model solution of zeolite

\begin{tabular}{|c|c|c|c|c|}
\hline \multirow{2}{*}{$\begin{array}{c}\text { The contact time of the } \\
\text { sorbent with the model } \\
\text { solution, min }\end{array}$} & $\begin{array}{c}\text { Uranium content in the } \\
\text { mother liquor after } \\
\text { sorption, mg / dm3 }\end{array}$ & \multicolumn{2}{|c|}{$\begin{array}{c}\text { Uranium } \\
\text { recovery } \\
\text { in sorbent }\end{array}$} & \multirow{2}{*}{$\begin{array}{c}\text { Sorption capacity of zeolite } \\
\text { for uranium, mg / g sorbent }\end{array}$} \\
\cline { 3 - 4 } & 1.28 & 0.065 & 50.9 & \\
\hline 30 & 0.26 & 0.117 & 90.1 & 0.0325 \\
\hline 60 & 0.23 & 0.118 & 91.1 & 0.0585 \\
\hline 120 & 0.20 & 0.120 & 92.3 & 0.0590 \\
\hline 180 & 0.18 & 0.121 & 92.9 & 0.0600 \\
\hline 300 & & & & 0.0605 \\
\hline
\end{tabular}

It follows from the table that in the first hour of the process over $90 \%$ of uranium is extracted, i.e. Uranium sorption proceeds quite actively, however, the natural sorbent - zeolite - has a low sorption capacity.

Uranium sorption by zeolite was confirmed by scanning electron microscopy (Figure 1). However, the main disadvantage of natural ion-exchange materials remains low sorption capacity, as evidenced by the calculated data obtained in the process of research.
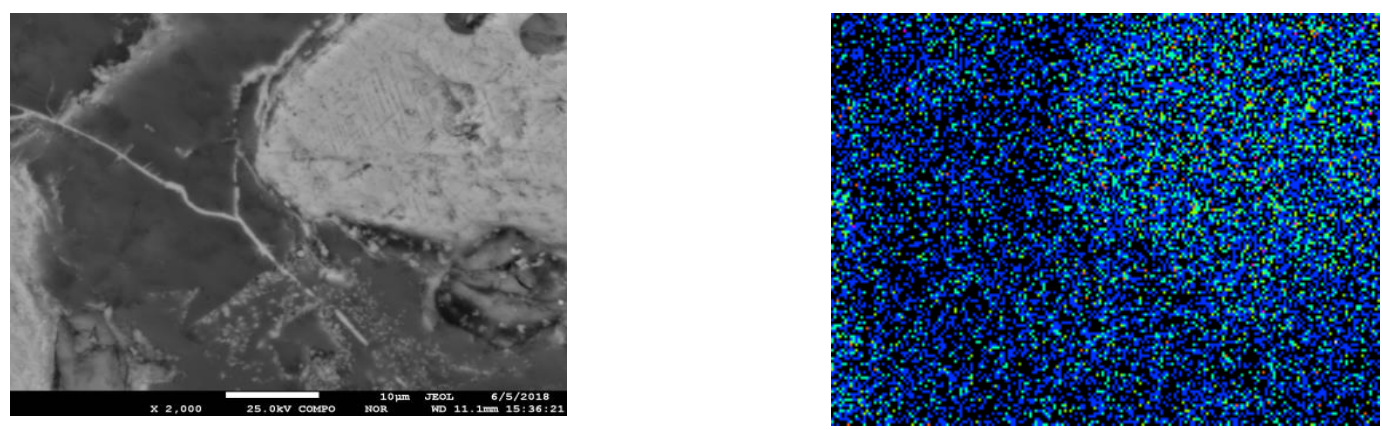


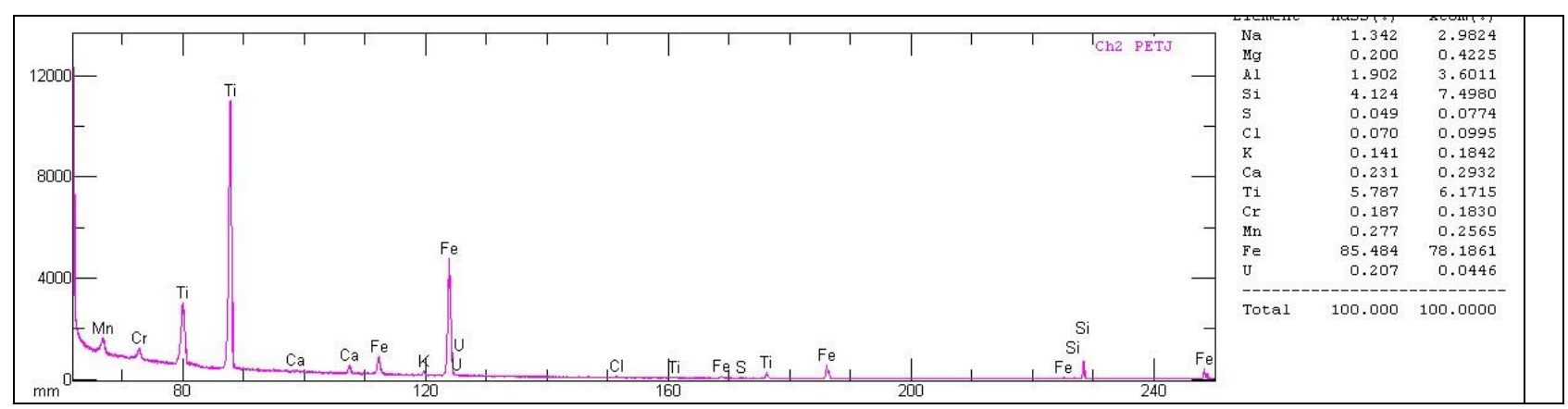

Figure 1 - Scanning electron microscopy of zeolite after sorption of uranium from model solutions

Based on the results obtained, the use of natural minerals in the treatment of liquid waste is acceptable from an environmental and economic point of view. However, such materials do not have the necessary sorption properties, so they must be further modified.

\section{REFERENCES}

1. Kenzhaliyev, B., Berkinbayeva, A., Sharipov, R. Extraction of Pd and Pt from dead catalysts using the leaching reagents // Metallurgical and Mining Industry. -2015. -Vol.7 (4). -P.132.

2. Kenzhaliyev, B.K., Iskhakova, R.R., Dosymbayeva, Z.D. Sorption extraction of noble and nonferrous metals from process leaching solutions // American Journal of Applied Sciences -2015. 12 (11). - P. 875.

3. Yessengaziyev A. Kenzhaliyev B. Berkinbayeva A., Sharipov R. Suleimenov E. Electrochemical extraction of $\mathrm{Pb}$ and $\mathrm{Zn}$ from a collective concentrate using a sulfur-graphite electrode as a cathode // Journal of Chemical Technology and Metallurgy. Sofia. -2017. -Vol. -52. -P.975-980.

4. Kenzhaliyev B.K., Berkinbayeva A.N., Dosymbayeva Z.D., Sharipov R.Kh. Extraction Of Non Ferrous And Noble Metals From Mill Tailing By Solutions In The Presence Of Oxidizing Agents // International Journal of Engineering and Applied Sciences (IJEAS). -2017. ISSN: 2394-3661. Vol. 4. -Issue 8. - P 93-95.

5. Cheira M. F., Atia B. M., Kouraim M. N. Uranium (VI) recovery from acidic leach liquor by Ambersep 920U SO 4 resin: Kinetic, equilibrium and thermodynamic studies // Journal of Radiation Research and Applied Sciences. -2017. -Vol. 10. -Issue 4. -P. 307-319. https://doi.org/10.1016/j.jrras.2017.07.005

6. Shakur H.R., Rezaee E. Kh., Abdi M.R., Azimi G. Highly selective and effective removal of uranium from contaminated drinking water using a novel PAN/AgX/ZnO nanocomposite // Microporous and Mesoporous Materials. -2016. -Vol. 234. -P. 257-266. doi.org/10.1016/j.micromeso.2016.07.034

7. Pfano M. N., Nikita T.T., Hlanganani T. Sorption of uranium (VI) onto hydrous ferric oxidemodified zeolite: Assessment of the effect of $\mathrm{pH}$, contact time, temperature, selected cations and anions on sorbent interactions // Journal of Environmental Management. -2017. -Vol. 204. -Part 1.15 -P. 571-582. https://doi.org/10.1016/j.jenvman.2017.09.034

8. Peter J.R., Howard J.F. Natural and surfactant modified zeolites: A review of their applications for water remediation with a focus on surfactant desorption and toxicity towards microorganisms // Journal of Environmental Management. -2018. -Vol. 205. -P. 253-261.

9. Kenzhaliyev B.K., Surkova T.Yu., Berkinbayeva A.N. To the question of the intensification of the processes of uranium extraction from refractory raw materials // Journal Metalurgija. -2018. -ISSN 0543-5846. -P. 75-78. 